Jurnal Tarbawi: Jurnal Ilmu Pendidikan p-ISSN:1858-1080 | e-ISSN: 2615-6547

Vol 14, No. 02, Desember 2018 , pp. 45-50

\title{
PENGARUH KEGIATAN KULIAH UMUM TERHADAP PENINGKATAN PEMAHAMAN KONSEP METODOLOGI PENELITIAN MAHASISWA SEMESTER 7 JURUSAN TADRIS BIOLOGI FTIK IAIN KERINCI
}

\author{
Dewi Juita $^{1}$, Yusmaridi $\mathbf{M}^{2}$ \\ ${ }^{1}$ Institut Agama Islam Negeri Kerinci \\ ${ }^{2}$ Universitas Islam Negeri Imam Bonjol Padang \\ e-mail: dewijuita@iainkerinci.ac.id
}

\begin{abstract}
This study aims to determine the impact of increasing understanding of the methodological concepts of research in 7th semester students of the Biology Department of FTIK, IAIN Kerinci. This was a pre-experimental method with the design of one group pre-test post test design. The sample in this study were 84 students of the 7 th semester who attended public lectures. Public lectures are given by lecturers who are already professionals in their fields both in qualitative research and quantitative research. Understanding the material of student research methodology is obtained from the matter of understanding the concept of research methodology that is shared with students after general lecture activities are held. The general lecture activity turned out to have an impact on increasing students 'understanding of the concepts of the research methodology material which can be seen from the NGain value of students' understanding of each indicator. The N-Gain value in the indicator exemplifies and classifies are 0.56 and 0.31 which are in the medium category. The N-Gain value on the indicator comparing and explaining is 0.15 which is in the low category. The 7 th semester students had better understanding of the material because in the general lecture activity the speaker presents the material in accordance with the problems faced by 7 th semester students who are undergoing the process of making proposals.
\end{abstract}

Keyword: Public Lecture, Understanding of Concepts, Research Methodology, Biology.

\begin{abstract}
Abstrak: Penelitian ini bertujuan untuk mengetahui dampak peningkatan pemahaman konsep metodologi penelitian mahasiswa semester 7 Jurusan Tadris Biologi FTIK IAIN Kerinci. Metode penelitian yang digunakan adalah pre experimental dengan desain one group pre-test post test design. Sampel pada penelitian ini adalah semua mahasiswa semester 7 yang menghadiri kegiatan kuliah umum yang berjumlah 84 orang. Kuliah umum diberikan oleh dosen-dosen yang sudah profesional di bidangnya baik itu dalam penelitian kualitatif maupun penelitian kuantitatif. Pemahaman materi metodologi penelitian mahasiswa diperoleh dari soal pemahaman konsep metodologi penelitian yang dibagikan kepada mahasiswa setelah kegiatan kuliah umum dilaksanakan. Kegiatan kuliah umum ternyata berdampak terhadap peningkatan pemahaman konsep mahasiswa terhadap materi metodologi penelitian yang dapat dilihat dari nilai N-Gain pemahaman mahasiswa pada masing-masing indikator. Nilai N-Gain pada indikator mencontohkan dan mengklasifikasikan adalah 0,56 dan 0,31 yang berada pada kategori sedang. Nilai N-Gain pada indikator membandingkan dan menjelaskan adalah 0,15 yang berada pada kategori rendah. Mahasiswa semester 7 lebih memahami materi karena pada kegiatan kuliah umum tersebut pemateri menyajikan materi sesuai dengan masalah yang dihadapi mahasiswa semester 7 yang sedang menjalani proses pembuatan proposal.
\end{abstract}

Kata Kunci: Kuliah Umum, Pemahaman Konsep, Metodologi Penelitian, Biologi. 


\section{PENDAHULUAN}

Kemampuan mahasiswa dalam menjawab pertanyaan dosen penguji ketika pelaksanaan ujian seminar dan ujian skripsi harus diiringi dengan kemampuan yang baik dari mahasiswa terhadap proposal skripsi dan skripsi yang telah mereka kerjakan. Kemampuan yang dimaksud terutama pada kemampuan menjelaskan metodologi penelitian yang mereka gunakan dalam karya ilmiah yang mereka kerjakan. Menjelaskan apa yang mereka kerjakan menggunakan bahasa sederhana yang mereka kuasai. Namun kenyataan yang diperoleh dari hasil wawancara dengan beberapa dosen tadris biologi FTIK IAIN Kerinci diperoleh bahwa dosen banyak yang berkeluh kesah ketika ujian seminar proposal dan ujian skripsi. Dosen mengeluh karena banyaknya mahasiswa yang tak mampu pertanyaan menjawab dosen pada Bab III di bagian skripsi mereka. Mahasiswa tak menjawab dan tak berkomentar terkait kenapa memilih metode penelitian tersebut. Selanjutnya, penulis juga mewawancarai beberapa mahasiswa semester 7 yang diperoleh bahwa mereka memang masih kurang memahami materi metodologi penelitian yang berdampak pada pembuatan skripsi yang bersifat asal jadi. Mereka cenderung untuk berpatokan kepada skripsi senior bukan berdasarkan pemahaman yang mereka peroleh.

Melihat permasalahan ini, penulis berinisiatif untuk bagaimana mahasiswa semester 7 yang telah melewati masa perkuliahan terutama mata kuliah metodologi penelitian ini dapat memperoleh pemahaman yang lebih baik. Penulis mengadakan kegiatan kuliah umum atas nama kegiatan jurusan yang tujuan dan sasarannya adalah untuk meningkatkan pemahaman konsep mahasiswa semester 7 jurusan tadris Biologi pada materi metodologi penelitian. Kuliah umum menurut KBBI adalah ceramah tentang masalah tertentu yang boleh dihadiri oleh mahasiswa dari berbagai jurusan. Masalah tertentu disini adalah masalah peningkatan kemampuan pembuatan skripsi mahasiswa khususnya dalam pemahaman konsep mahasiswa terhadap materi metodologi penelitian. Mahasiswa yang hadir adalah mahasiswa jurusan tadris Biologi semester 7 yang sedang aktif dalam proses pembuatan proposal skripsi.

Kuliah umum dilaksanakan selama 1 hari yang diiisi oleh dosen-dosen yang memang ahli di bidang metodologi penelitian. Materi kuliah umum berupa penekanan pada penelitian kuantitatif dan penelitian kualitatif. Penekanan terhadap teori serta teknik analisis data. Materi kuliah umum sudah disesuaikan dengan kebutuhan mahasiswa dan dosen serta disetujui oleh ketua jurusan. Pemahaman merupakan terjemahan dari istilah understanding yang diartikan sebagai penyerapan arti suatu materi yang dipelajari. Anderson (2010) menjelaskan definisi memahami, yaitu: "memahami adalah mengkonstruk makna atau pengertian berdasarkan pengetahuan awal yang dimiliki, mengaitkan informasi yang baru dengan pengetahuan yang telah dimiliki, atau mengintegrasikan pengetahuan yang baru ke dalam skema yang telah ada dalam pemikiran siswa". Dengan 
pemahaman, mahasiswa diminta untuk membuktikan bahwa ia memahami hubungan yang sederhana diantara fakta-fakta atau konsep.

Konsep adalah suatu abstraksi yang menggambarkan ciri-ciri umum sekelompok objek, peristiwa atau fenomena lainnya. Konsep merupakan kategori yang kita berikan pada stimulus yang ada di lingkungan kita. Konsep menyediakan skema terorganisasi untuk mengasimilasi stimulus baru dan menentukan hubungan di dalam dan diantara kategori-kategori. Belajar konsep merupakan hasil utama pendidikan. Konsep merupakan batu pembangun berpikir. Untuk memecahkan masalah, seorang siswa harus mengetahui aturan-aturan yang relevan dan aturanaturan ini didasarkan pada konsep-konsep yang diperolehnya (Dahar, 2006).

Pemahaman konsep adalah tingkat kemampuan yang mengharapkan siswa mampu memahami arti dari konsep, situasi, serta fakta yang diketahuinya. Pengetahuan konseptual merupakan dasar pemahaman. Menurut Anderson (2010), kemampuan pemahaman dapat dijabarkan menjadi tujuh, yaitu:

1. Menafsirkan (Interpreting), siswa mampu mengubah informasi dari satu bentuk ke bentuk lain. Menginterpretasikan meliputi perubahan kata-kata menjadi kata-kata lain. Misalnya gambar menjadi kata-kata, kata-kata menjadi gambar, angka menjadi kata-kata dan sejenisnya.

2. Mencontohkan (Exemplifying), siswa mampu memberikan contoh tentang konsep atau prinsip umum. Mencontohkan meliputi proses identifikasi ciri-ciri pokok dari konsep atau prinsip umum dan menggunakan ciri-ciri pokok dari konsep atau prinsip umum dan menggunakan ciriciri ini untuk memilih atau membuat contoh.

3. Mengklasifikasikan (Classifying), siswa mengetahui bahwa sesuatu (contoh atau kejadian tertentu) termasuk dalam kategori tertentu (misal konsep atau prinsip). Mengklasifikasi meliputi penemuan ciri-ciri atau pola-pola yang relevan, yang cocok dengan contoh spesifik dan konsep atau prinsip umum.

4. Meringkas (Summarizing), siswa mampu mengemukakan satu kalimat yang merepresentasikan informasi yang diterima atau mengabstraksikan sebuah tema.

5. Menyimpulkan (Inferring), penemuan pola dalam rangkaian contoh-contoh atau kejadiankejadian. Menyimpulkan terjadi ketika siswa mampu meringkas atau mengabstraksikan sebuah konsep atau prinsip yang terdiri dari suatu rangkaian contoh-contoh atau kejadian-kejadian dengan menarik hubungan diantara ciri-ciri dari rangkaian contoh-contoh atau kejadiankejadian tersebut.

6. Membandingkan (Comparing), melibatkan proses mendeteksi persamaan dan perbedaan antara dua atau lebih objek, peristiwa, ide, masalah, atau situasi. Membandingkan menentukan hubungan antara dua ide, dua objek, dan semacamnya. 
7. Menjelaskan (Explaining), siswa mampu membangun dan menggunakan model sebab-akibat dari suatu sistem. Model ini dapat diturunkan dari teori, atau didasarkan pada hasil penelitian atau pengalaman. Penjelasan yang lengkap meliputi proses membuat model sebab-akibat, yang mencakup setiap bagian utama dalam suatu sistem atau setiap peristiwa penting dalam rangkaian peristiwa, dan proses menggunakan model untuk menentukan perubahan dalam satu bagian dalam sistem atau hubungan dalam rangkaian yang mempengaruhi perubahan pada bagian ini.

Soal pemahaman konsep yang diberikan kepada mahasiswa semester 7 adalah soal pada indkator mencontohkan (Exemplifying) mengklasifikasikan (Classifying), membandingkan (Comparing) dan menjelaskan (Explaining). Soal dalam bentuk soal obyektif yang terdiri dari 20 soal pemahaman konsep metodologi penelitian

\section{METODOLOGI}

Metode penelitian yang digunakan adalah metode pre-experimental. Penulis menggunakan metode ini karena penulis tidak menggunakan kelas pembanding sebagai bentuk upaya penulis dalam menjelaskan keunggulan suatu metode. Dalam penggunaan metode pre-experimental, penulis tidak menggunakan hipotesis yang disebabkan karena penulis tidak memiliki asumsi keberpihakan terhadap rumusan masalah. Penulis memiliki sampel yang terbatas berupa mahasiswa semester 7 yang sedang mengerjakan proposal skripsi yang berjumlah 84 mahasiswa. Penulis juga hanya ingin melihat pengaruh penggunaan kuliah umum terhadap peningkatan pemahaman konsep mahasiswa terhadap materi metodologi penelitian.

Desain penelitian ini adalah One group pre-test post-test design. Pada penelitian ini penulis memberikan pre-test berupa soal pemahaman konsep metodologi penelitian kepada mahasiswa. Selanjutnya penulis memberikan perlakukan atau treatment kepada mahasiswa berupa pemberian kuliah umum oleh para ahli metodologi penelitian (dosen pengampu mata kuliah metodologi penelitian). Kegiatan kuliah umum diiisi dengan penjelasan menarik serta tanya jawab yang interaktif antara pemateri dengan mahasiswa sebagai sampel penelitian. Pada bagian akhir, penulis memberikan tes kembali yang disebut dengan post-test yang juga berisikan soal pemahaman konsep terkait materi metodologi penelitian yang soalnya setara dengan soal pre-test yang telah diberikan oleh penulis di awal kegiatan kuliah umum. Soal setara yang dimaksud adalah soal yang memiliki indikator kemampuan yang sama dengan soal yang berbeda.

Adapun instrumen yang digunakan oleh penulis adalah soal pemahaman konsep yang diuji validitas dan reliabilitas soalnya. Soal yang diberikan kepada sampel penelitian adalah soal dalam bentuk objektif atau pilihan ganda dengan pilihan jawaban sebanyak 5 (lima) pilihan jawaban yang 
berjumlah 20 soal yang terdiri dari 4 (empat) indikator pemahaman konsep. Peningkatan pemahaman konsep mahasiswa pada materi metodologi penelitian dilihat dari nilai N-Gain (Hake, 1999)

\section{HASIL PENELITIAN DAN PEMBAHASAN}

Dari hasil penelitian diperoleh persentase indikator pemahaman konsep mahasiswa pada indikator mencontohkan, mengklasifikasikan, membandingkan, dan menjelaskan yang dapat dilihat pada Gambar 1.

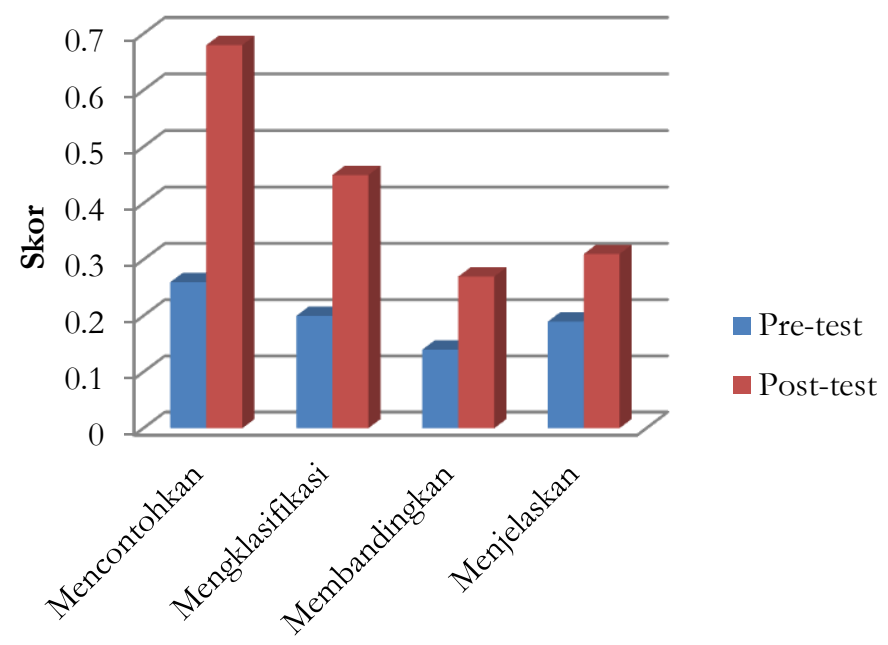

Gambar 1. Hasil Pemahaman Konsep Mahasiswa

Berdasarkan gambar di atas terlihat bahwa skor pre-test dan skor post-test untuk indikator mencontohkan adalah 0,26 dan 0,68, skor pre-test dan skor post-test untuk indikator mengklasifikasikan adalah 0,20 dan 0,45 , skor pre-test dan skor post-test untuk indikator membandingkan adalah 0,14 dan 0,27, dan skor pre-test dan skor post-test untuk indikator menjelaskan adalah 0,19 dan 0,31. Kemudian nilai N-Gain untuk indikator mencontohkan adalah 0,56 dengan kategori sedang, nilai $N$-Gain untuk indikator mengklasifikasikan adalah 0,31 dengan kategori sedang, nilai $N$-Gain untuk indikator membandingkan adalah 0,15 dengan kategori rendah serta nilai $\mathrm{N}$-Gain untuk indikator menjelaskan adalah 0,15 dengan kategori rendah.

Peningkatan pada indikator mencontohkan mengalami peningkatan yang mencolok hal ini disebabkan karena pemateri cenderung lebih menguraikan beberapa contoh jenis proposal skripsi yang menggunakan jenis penelitian kualitatif dan kuantitatif. Pemberian contoh berupa judul-judul skripsi yang telah pernah ada ruang lingkup pendidikan. Selanjutnya, memang kegiatan kuliah umum ini juga bertujuan untuk membedah penelitian yang telah ada. Sedangkan pada indikator membandingkan dan menjelaskan memiliki peningkatan dalam kategori rendah. Hal ini disebabkan karena semua penjelasan pemateri tidak semua terserap oleh mahasiswa, dan kecenderungan 
mahasiswa yang lebih tertarik dengan aplikasi dari metode penelitian dalam bentuk pembuatan skripsi.

Pada indikator membandingkan, mahasiswa dituntut untuk mampu mendeteksi persamaan dan perbedaan antara penelitian kualitatif dan kuantitatif dalam metode penelitian. Menggunakan rancangan desain yang tepat serta pengolahan data yang sesuai dengan rancangan desain yang diperoleh. Pada indikator menjelaskan, mahasiswa dituntut untuk mampu menjelaskan secara rinci terkait jenis rancangan penelitian yang disertai dengan teknik analisis datanya.

\section{PENUTUP}

Kegiatan kuliah umum ternyata berdampak terhadap peningkatan pemahaman konsep mahasiswa terhadap materi metodologi penelitian yang dapat dilihat dari nilai N-Gain pemahaman mahasiswa pada masing-masing indikator. Nilai N-Gain pada indikator mencontohkan dan mengklasifikasikan adalah 0,56 dan 0,31 yang berada pada kategori sedang. Nilai N-Gain pada indikator membandingkan dan menjelaskan adalah 0,15 yang berada pada kategori rendah. Mahasiswa semester 7 lebih memahami materi karena pada kegiatan kuliah umum tersebut pemateri menyajikan materi sesuai dengan masalah yang dihadapi mahasiswa semester 7 yang sedang menjalani proses pembuatan proposal.

\section{REFERENSI}

Anderson, L.W. dan Karthwol D.R. (2010). Pembelajaran, Pengajaran, dan Asesmen. Yogyakarta: Pustaka pelajar.

Arifin, Zainal. (2014). Penelitian Pendidikan. Bandung: Remaja Rosdakarya

Aunurrahman. (2009). Belajar dan Pembelajaran. Bandung: Alfabeta

Dahar, R.W. (2006). Teori-teori Belajar dan Pembelajaran. Jakarta: Erlangga.

Hake, R. (1999). Analyzing Change/Gain Scores. Indiana: Indiana University

Sabdulloh, Uyoh. (2010). Pedagogik Ilmu Mendidik. Bandung: Alfabeta

Slameto. (2015). Belajar dan Faktor-Faktor yang Mempengarubinya. Jakarta: Rineka Cipta

Sukmadinata, Nana Syaodih. (2009). Landasan Psikologi Proses Pendidikan. Bandung: Remaja Posdakarya

Susanto, Ahmad. (2016). Teori Belajar Dan Pembelajaran. Jakarta: Prenada Media Group http://kbbi.web.id, diakses tanggal 12 November 2018 